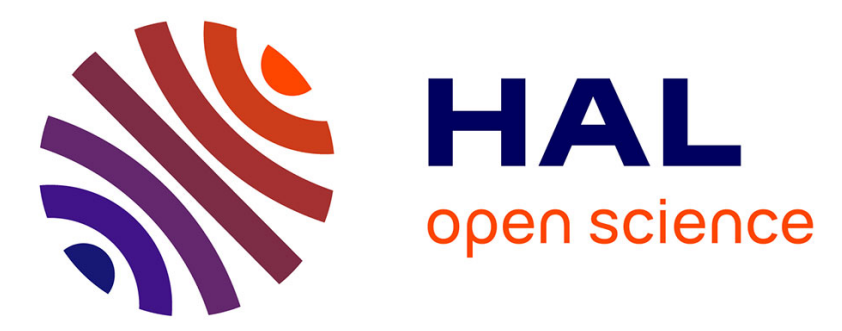

\title{
Modelling range dynamics of terricolous lichens of the genus Peltigera in the Alps under a climate change scenario
}

Chiara Vallese, Juri Nascimbene, Paolo Giordani, Renato Benesperi, Gabriele Casazza

\section{To cite this version:}

Chiara Vallese, Juri Nascimbene, Paolo Giordani, Renato Benesperi, Gabriele Casazza. Modelling range dynamics of terricolous lichens of the genus Peltigera in the Alps under a climate change scenario. Fungal Ecology, 2021, 49, pp.101014. 10.1016/j.funeco.2020.101014 . hal-03142874

\section{HAL Id: hal-03142874 \\ https://hal-amu.archives-ouvertes.fr/hal-03142874}

Submitted on 17 Feb 2021

HAL is a multi-disciplinary open access archive for the deposit and dissemination of scientific research documents, whether they are published or not. The documents may come from teaching and research institutions in France or abroad, or from public or private research centers.
L'archive ouverte pluridisciplinaire HAL, est destinée au dépôt et à la diffusion de documents scientifiques de niveau recherche, publiés ou non, émanant des établissements d'enseignement et de recherche français ou étrangers, des laboratoires publics ou privés.

\section{(ㅇ)(1) $\$$}

Distributed under a Creative Commons Attribution - NonCommercial - NoDerivatives 44.0 


\title{
Modelling range dynamics of terricolous lichens of the genus Peltigera in the Alps under a climate change scenario
}

\author{
Chiara Vallese a , Juri Nascimbene ${ }^{\text {a }}$, Paolo Giordani ${ }^{\mathrm{b}}$, Renato Benesperi ${ }^{\mathrm{c}}{ }^{*}$, \\ Gabriele Casazza ${ }^{\mathrm{d}}$ \\ a Department of Biological Geological and Environmental Sciences, University of Bologna, Italy \\ b Dipartimento di Farmacia (DIFAR), Università di Genova, Italy \\ ${ }^{c}$ Dipartimento di Biologia, Università degli Studi di Firenze, Italy \\ d Institut Méditerranéen de Biodiversité et d'Ecologie Marine et Continentale Aix Marseille Univ, Avignon Univ, CNRS, IRD, IMBE Technopôle de L'Arbois- \\ Méditerranée, BP 80, 13545 Aix-en-Provence Cedex 4, France
}

\author{
Keywords: \\ Asexual dispersal \\ Functional traits \\ Sexual dispersal \\ Species distribution modelling \\ Thallus thickness \\ Trade-off between dispersal and \\ establishment \\ Water-use strategies
}

\begin{abstract}
A B S T R A C T
Climate change is expected to strongly impact biodiversity in Alpine ecosystems and species distribution modelling is increasingly used to provide anticipatory information to guide conservation. In this study, (1) we quantified the range loss, range gain, range change and range turnover caused by climate change in the genus Peltigera a group of terricolous lichens widespread across the Alps, and then (2) we evaluated the relationships between the predictors of range dynamics and functional traits. Our results indicate moderate range dynamics for species of the genus Peltigera across the Alps under a climate change scenario. This would imply a relative stability and resistance of these lichens to climate change that may reflect the local persistence of the species under sub-optimal conditions. Our results also suggest that range dynamics could be associated with functional traits mainly related to water-use strategies and to a trade-off between dispersal and establishment ability. This finding suggests that functional traits may strongly modulate the lichen response to climate change and that species with similar functional traits are prone to similar selective pressures.
\end{abstract}

\section{Introduction}

There is an increasing amount of evidences that climate change will impact ecosystems and society considerably in the next decades (IPCC, 2014). Even if the effects are expected in most terrestrial ecosystems (Schmitz et al., 2003; Rands et al., 2010), most predictive models concur that the rate of temperature change caused by increased levels of greenhouse gases in the atmosphere will be particularly impacting both at high latitudes (Holland and Bitz, 2003) and on high elevation environments (Gobiet et al., 2014; Pepin et al., 2015). In the Alps, an annual average increase of $1.5^{\circ} \mathrm{C}\left(0.25^{\circ} \mathrm{C}\right.$ per decade $)$ is expected in the first half of the $21 \mathrm{st}$ century. This rate is expected to accelerate reaching an increase of

\footnotetext{
* Corresponding author.

E-mail address: renato.benesperi@unifi.it (R. Benesperi).
}

$3.3{ }^{\circ} \mathrm{C}\left(0.36{ }^{\circ} \mathrm{C}\right.$ per decade $)$ within the second half of the $21 \mathrm{st}$ century. Precipitation is also expected to change, decreasing in summer, particularly in the south of the Alps, and increasing in winter (Heinrich et al., 2013; Gobiet et al., 2014). In addition, global radiation and relative humidity are expected to change causing cascading impacts such as floods, droughts, decreasing snow cover, and other natural hazards (Gobiet et al., 2014).

Apart from direct consequences on human activities in Alpine areas, climate change is also expected to impact Alpine ecosystems that are an irreplaceable reserve of biodiversity, including recognized endemism hotspots (Nagy et al., 2003). As the geographic and local ranges of most plants and animals living in these ecosystems are influenced by climatic factors, any shift in magnitude or variability of climatic factors can impact the Alpine biota considerably (Bellard et al., 2012). In particular, range size reduction (Loarie et al., 2008; Dirnböck et al., 2011; Casazza et al., 2014; Guerrina et al., 2016) and altitudinal shifts (Lenoir et al., 2008; Chen et al., 2011; 
Alexander et al., 2017; Dainese et al., 2017; Rumpf et al., 2018) are the most common responses already observed, posing concern for biodiversity conservation and for ecosystem functioning.

Besides observational and long-term monitoring studies, whose potential for tracking climate change impacts on the Alpine biota is irreplaceable (Lamprecht et al., 2018), predictive modelling (e.g. SDM - species distribution models) is increasingly used to forecast the consequences of climate change (Beaumont et al., 2008) providing anticipatory information to guide conservation efforts. However, while this approach is widely used for animals and plants (Thuiller et al., 2005; Parmesan, 2006; Brambilla and Ficetola, 2012; Alexander et al., 2017), its application to poorly detectable taxa is still in its infancy, as in the case of lichens (Ellis, 2019), a complex symbiotic network mainly composed of a fungus (mycobiont) and a photosynthetic partner (photobiont), and also hosting diverse microbial communities (Grube et al., 2009).

With roughly 3000 species, lichens greatly contribute to biodiversity (Nimis et al., 2018) and ecosystem functioning (Zedda and Rambold, 2015) in the Alps. In particular, terricolous lichens that are among the main components of the biological soil crusts (Türk and Gärtner, 2001) are involved in crucial ecosystem processes, including nutrient cycling, soil stabilization, and water dynamics (Elbert et al., 2012). As an example, cyanolichen-dominated soil crusts (i.e. lichens with cyanobacterial photobiont in contrast to chlorolichens that host green algae) are very effective in nitrogen and carbon fixation (Pietrasiak et al., 2013). This is fundamental for triggering ecosystem succession in oligotrophic environments, as for example in periglacial areas (Nascimbene et al., 2017). Similarly to epiphytes (Bässler et al., 2016; Nascimbene and Spitale, 2017), terricolous lichens may be strongly impacted by climate change that is expected to cause community-level effects, such as species loss and compositional shifts (Escolar et al., 2012). These effects are likely to explain range dynamics (i.e., the inter-relationship between range lost and gained) of single species, thus providing a basis for species distribution modelling of these organisms.

The sensitiveness of lichens to climatic factors is mainly related to their poikilohydric nature (Oliver et al., 2000). Their metabolic activity (e.g. photosynthesis) depends on the water content of the thallus which tends to reach an equilibrium with that of the surrounding environment (Insarov and Schroeter, 2002; Green et al., 2008). Thus, the physiology of lichens is closely coupled with ambient temperature and moisture conditions, which influence thallus water saturation and desiccation (Gauslaa, 2014; Merinero et al., 2014). This condition is particularly restrictive for cyanolichens whose photosynthetic activity can be triggered exclusively by liquid water instead of air humidity, as in the case of chlorolichens (Lange et al., 1986). From this perspective, there is increasing awareness on the fact that the response of lichens to climatic factors may be mediated by functional traits mainly related to water-use strategies, photosynthetic performance, and nitrogen fixation (Giordani et al., 2012; Matos et al., 2015). For example, thallus thickness influences the water holding capacity of the species. Thick thalli may need more time than thin thalli to saturate but they are able to store higher amounts of water, thus sustaining their metabolic activity for longer. With decreasing precipitation frequency and the negative effect of warming on air humidity, the water-storage strategy associated with thick thalli may be more favourable than the rapid moisture-uptake strategy associated with thin thalli (Hurtado et al., 2020). On the other hand, under changing climate a trade-off between dispersal and establishment ability may determine range dynamics of the species (Löbel and Rydin, 2010). Lichens may produce both sexual and asexual diaspores (Nash, 2008). The former are expected to be more suitable for longrange dispersal (Ronnås et al., 2017) but imply the availability of a new photobiont and successful re-establishment of the lichen symbiosis. The latter are more suitable for local dispersal and establishment due to the simultaneous occurrence of the symbiotic partners (Scheidegger and Werth, 2009; Werth et al., 2014). Depending on the speed and size of environmental change, asexual diaspores would be more effective in resisting non-optimal conditions and reestablishing and developing viable populations in newly available habitats where a species' climatic suitability is met (Ellis, 2019).

In this study, we (1) quantified range dynamics of a selected genus of terricolous lichens widespread across the Alps, and then (2) we evaluated the potential relationships between the descriptors of range dynamics and some selected functional traits that may reflect the response of lichens to climate. We selected terricolous species in the genus Peltigera as a suitable model system since (a) they are cyanolichens (including two tripartite species that also contain green algae), thus functionally relevant components of the biological soil crusts of the Alps and potentially very responsive to changing climate; (b) their distribution spans several elevational belts, including both strictly arctic-alpine species of high elevation ranges and temperateboreal species mainly related to the montane and subalpine belts, making it possible to account for a gradient of inter-specific sensitivity to climate change; (c) they have strong inter-specific variability of functional traits (e.g. thallus thickness), including contrasting dispersal strategies (sexual and asexual); (d) species occurrences data for these large foliose lichens are relatively abundant and more taxonomically reliable compared to small crustose lichens that are scarcely detectable in the field and to several fruticose lichens (e.g. those in the genus Cladonia) that require laboratory techniques and equipment for correct identification. This would allows a robust use for species distribution modelling.

\section{Materials and methods}

\subsection{Study area, species selection and occurrence data}

The study area includes the whole Alps, as defined according to the International Unified Orographic Subdivision of the Alpine System (Marazzi, 2005). According to the altitudinal distribution of Peltigera in this area (Nimis et al., 2018), the 15 species that rise up to the alpine belt were selected for our modelling analysis (Table 1). Species occurrence data were obtained from the GBIF network (https://www.gbif.org/), from the Information system on the Italian lichens - ITALIC 5.0 (Nimis and Martellos, 2017) and from the personal databases of the authors. Finally, to mitigate pseudoreplication, occurrences of each species were spatially filtered by retaining only one occurrence per grid cell of about $1 \times 1 \mathrm{~km}$ spatial resolution. A final data set of 33,432 occurrences, ranging from 8214 to 26 occurrences per species (Table 1), was used in the analyses.

\subsection{Bioclimatic variables}

Nineteen bioclimatic variables representative of the period 1979-2013 were downloaded from CHELSA database website (http://chelsa-climate.org/) at a 30 -s (i.e., about $1 \mathrm{~km} \times 1 \mathrm{~km}$ ) spatial resolution (Karger et al., 2017) for the extent of Europe. These variables combine together temperature and precipitation in order to obtain biologically relevant variables that are assumed to be important for limiting the distribution of lichen species (Nascimbene et al., 2016). To reduce collinearity and to minimize model overfitting, we performed a pairwise Pearson correlation between bioclimatic predictors. We retained four predictors that were not highly correlated $(r \leq|0.70|)$ : BIO1-Annual Mean Temperature, BIO4-Temperature Seasonality, BIO12-Annual Precipitation and BIO15-Precipitation Seasonality. 
Table 1

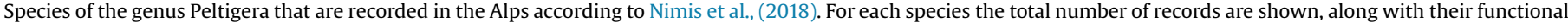

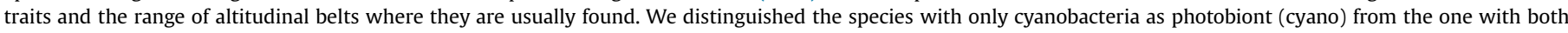

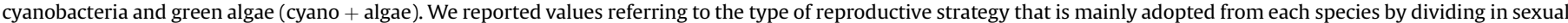

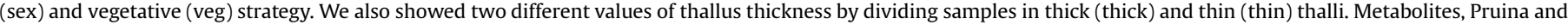

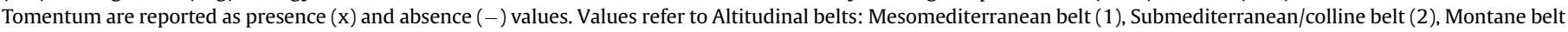
(3), Subalpine belt (4), Alpine (5) and Nival (6).

\begin{tabular}{|c|c|c|c|c|c|c|c|c|}
\hline Species & Record & Photobiont & Repr. & Metab. & Thickn. & Pruina & Toment. & Belt \\
\hline -Peltigera aphthosa & 2827 & cyano + algae & sex & $\mathrm{x}$ & thick & - & $\mathrm{x}$ & $3-6$ \\
\hline -Peltigera canina & 5466 & cyano & sex & - & thin & - & $\mathrm{x}$ & $1-5$ \\
\hline -Peltigera didactyla & 2679 & cyano & veg & - & thin & - & $\mathrm{x}$ & $2-6$ \\
\hline -Peltigera elisabethae & 357 & cyano & veg & $\mathrm{x}$ & thin & $\mathrm{x}$ & - & $3-5$ \\
\hline -Peltigera kristinssonii & 349 & cyano & sex & - & thin & - & $\mathrm{x}$ & $3-5$ \\
\hline -Peltigera lepidophora & 446 & cyano & veg & - & thin & - & $\mathrm{x}$ & $3-6$ \\
\hline Peltigera leucophlebia & 2747 & cyano + algae & sex & $\mathrm{x}$ & thin & - & $\mathrm{x}$ & $2-5$ \\
\hline -Peltigera malacea & 1330 & cyano & sex & $\mathrm{x}$ & thick & $\mathrm{x}$ & $\mathrm{x}$ & $3-5$ \\
\hline -Peltigera neckeri & 542 & cyano & sex & $\mathrm{x}$ & thick & $\mathrm{x}$ & - & $1-5$ \\
\hline -Peltigera polydactylon & 2054 & cyano & sex & $\mathrm{x}$ & thick & - & - & $2-5$ \\
\hline -Peltigera ponojensis & 121 & cyano & sex & - & thin & - & $\mathrm{x}$ & $2-5$ \\
\hline -Peltigera praetextata & 8214 & cyano & veg & - & thin & - & $\mathrm{x}$ & $1-5$ \\
\hline -Peltigera rufescens & 4471 & cyano & sex & - & thick & $\mathrm{x}$ & $\mathrm{x}$ & $1-6$ \\
\hline - Peltigera scabrosa. & 681 & cyano & sex & $\mathrm{x}$ & thick & - & - & $3-5$ \\
\hline -Peltigera venosa & 1122 & cyano + algae & veg & $\mathrm{x}$ & thick & - & - & $2-5$ \\
\hline
\end{tabular}

For future conditions (i.e., 2061-2080), we chose two representative concentration pathways representing moderate (RCP 4.5) and extreme (RCP 8.5) possible future emission trajectories and coded according to a possible range of radiative forcing values in the year 2100 relative to preindustrial values (IPCC, 2014) adopted by the Intergovernmental Panel on Climate Change for its fifth Assessment Report (AR5). For the purpose of this work, we discarded the representative concentration pathway representing optimistic possible future emission trajectories (i.e., RCP 2.6) because, under this climate, Mediterranean and Alpine ecosystems are predicted to remain within the climatic variability of the Holocene (Guiot and Cramer, 2016; Fauquette et al., 2018). We selected RCPs projections from five different General Circulation Models (GCM), which represent the physical processes that govern the general circulation of planetary atmosphere or oceans, following the recommendations of Sanderson et al. (2015). In particular, two models (CESM1-CAM5 and CESM1-BGC) were provided by the Community Earth System Model CESM, one model (MIROC5) by the International Centre for Earth Simulation ICES, one model (CMCC$\mathrm{CM}$ ) by the Centro Euro-Mediterraneo sui Cambiamenti Climatici and the last one (MP-ESM-MR) by the Max Planck Institute for Meteorology.

\subsection{Species distribution models}

Species occurrence data and the four selected variables were used to construct distribution models using Package Biomod2 (Thuiller et al., 2016) implemented in (R Development Core Team, 2008). To account for model-based uncertainties in the modelling process we used four SDM techniques belonging to three different categories of models: regression methods, decision trees methods and machine learning algorithms. In particular, multivariate adaptive regression splines (MARS - Friedman, 1991) and Generalized Mixed Models (GLM - McCullagh and Nelder, 1989) are regression methods, random forest ( $R F$ - Breiman, 2001) is a decision trees method and Maxent (Phillips et al., 2006) is a machine learning algorithm.

For each taxon we generated a set of pseudo-absences, setting the number and the method of selection of pseudo-absences according to Barbet-Massin et al. (2012). The split-sample crossvalidation was repeated 10 times, using a random subset (30\%) of the initial data set. Model performance was evaluated using two different evaluation measures: the area under the curve (AUC; Hanley and McNeil, 1982) of a ROC plot and the true skill statistic (TSS; Allouche et al., 2006). Eventually, because the choice of threshold is critical by increasing or decreasing prediction bias, we transformed continuous suitability maps into binary presenceabsence projections using three different thresholds implemented in the R package PresenceAbsence (Freeman and Moisen, 2008) for those performing equally or better than others (Liu et al., 2005; Cao et al., 2013): the method based on equal sensitivity and specificity, the method based on maximizing sensitivity and specificity, and the method based on maximizing the distance between the observed ROC plot and the top-left corner $(0,1)$ in a ROC plot.

\subsection{Spatial index for distribution under different time periods}

The percentage of predicted future range change ( $R C)$, in relation to the present-day predicted distribution, was estimated using the formula $\mathrm{RC}=100 \times(\mathrm{G}-\mathrm{L}) / \mathrm{PR}$, where $\mathrm{G}$ is the number of grid cells projected to be not suitable under present climate but suitable under future climate, $\mathrm{L}$ is the number of grid cells projected to be suitable under present climate but not suitable under future climate and PR is the number of grid cells projected suitable under current climatic scenario. A negative RC value indicates a loss in overall range, whereas a positive value indicates an increase in overall range size. The range turnover (RT) per cell of the climate envelope range was estimated using $R T=100 \times(L+G) /(P R+G)$. A RT value of 0 indicates no shift in range, whereas a value of 100 indicates a complete range shift when compared with the predicted range under current conditions. The percentage of range gain (RG) was calculated using the formula $R G=(G / P R) \times 100$, the percentage of range loss $(\mathrm{RL})$ was calculated by the formula $\mathrm{RL}=(\mathrm{L} / \mathrm{PR}) \mathrm{x} 100 . \mathrm{A}$ Kendall tau correlation coefficient was employed to determine the relationships between the percentage of RL, RG, RC and RT. We also performed a Kruskal-Wallis test in order to test any differences between future scenarios.

\subsection{Morpho-functional traits}

To understand which functional traits may be more useful to explain the degree of range shift, we considered traits that are potentially implicated, directly or indirectly, in the response of the Peltigera species to climatic factors, with particular reference to 
management of water and light, and to dispersal capability. Traits may shape current and future distribution of species in different ways. Some traits related to physiological performance of species may affect the tolerance of species to climate determining the climatic space potentially available to species and in turn their distribution. However, traits that determine reduced dispersal capability might hinder the species to establish in climatically suitable locations resulting in narrower climatic and geographical space occupied by the species than expected by climatic tolerance only (Soberon, 2010). Moreover, poor dispersal ability may affect future distribution of species not enabling them to keep pace with future climate change. We took into account the following traits related to physiological tolerance:

- Type of photobiont. Lichens in symbiosis with chlorococcoid algae, but which also have cyanobacteria in specialized structures called cephalodia perform better in dry conditions than lichens in symbiosis with cyanobacteria (Carniel et al., 2016).

- Thickness of the thallus. This characteristic is linked to the water retention capacity of the species: with the same environmental conditions, thicker thalli can maintain more water for a longer period of time than thin thalli (Phinney et al., 2018). Based on quantitative data obtained from Martínez (1999), this trait was applied as a categorical variable which can take two values: i) thick thallus $(>300 \mu \mathrm{m})$ and ii) thin thallus $(<300 \mu \mathrm{m})$.

- Presence or absence of pruina. The pruina consists of surface deposits of calcium oxalates which in the lichen thallus play both structural roles in the dehydration-rehydration cycles (Modenesi et al., 2000) and provide protection from solar radiation (Giordani et al., 2003).

- Presence or absence of tomentum. The tomentum has been proposed as an additional strategy for modulating water loss and $\mathrm{CO}_{2}$ diffusion within the thallus (Snelgar and Green, 1981).

- Presence or absence of secondary metabolites. These substances are synthesized in the cortex and/or in the medulla and are usually involved in photoprotective functions and are related to water potential (Gauslaa and Solhaug, 2004).

We took into account the following traits related to dispersal capability:

- Sexual or vegetative reproductive strategy. Sexual reproduction by ascospores enables species to dispersal for long distances while vegetative reproduction by isidia, or isidia-like structures (e.g. schizidia) only allows for short distance dispersal (Singh et al., 2015). This trait can affect the occupancy of the species' realised climatic niche limiting the climatic and geographical space occupied by the species.

Data on traits were retrieved from Vitikainen (1994); Goward et al. (1995) and Martínez (1999). Principal Component Analysis (PCA) was used to explore range variations according to the future scenarios with respect to the selected morpho-functional traits of the species. Range descriptors were used as active variables and traits as supplementary variables in the PCA. Spearman's correlations between both active and supplementary variables and the PCA dimensions were tested ( $\mathrm{p}<0.05$ as reference threshold). PCA was calculated using FactoMineR package (Lê et al., 2008) in $R$ environment.

\section{Results}

Under current climate conditions, model evaluation indices mainly indicated a good model performance for all modelling techniques in all species (Table 2). The highest AUC values ranged from 0.848 to 0.977 and TSS values ranged from 0.612 to 0.892 . No statistically significant differences were detected between the different climate change scenarios affecting the range change parameters.

\subsection{Range gain and range loss}

In general, under future climatic conditions range loss (RL) varied from $0.00 \%$ to $41.02 \%$ in RCP4.5 scenario and from $0.00 \%$ to $61.96 \%$ in the RCP 8.5 scenario, suggesting that Peltigera species will maintain the majority of their current range (blue shade in Figs. 1 and 2). The highest RL was detected in Peltigera didactyla, P. elisabethae, $P$. neckeri, $P$. polydactylon, and $P$. venosa showing a RL between $16.38 \%$ and $41.02 \%$ in RCP 4.5 scenarios and between $25.19 \%$ and $61.96 \%$ in RCP8.5 (Table 3, grey shade in Fig. $1 \mathrm{~b}-\mathrm{f}$ and Fig. $2 b-f)$. The range loss will mainly occur at low elevation in the peripheral parts of the Alps suggesting that in general species will contract their range toward the higher elevations of the mountain chain. The range gain (RG) is generally low, ranging from $0.01 \%$ to $18.64 \%$ in RCP 4.5 scenario and from $0.01 \%$ to $21.51 \%$ in RCP 8.5 scenario. The higher values were detected for Peltigera in Peltigera aphthosa, P. elisabethae, P. kristinssonii, $P$. polydactylon, and P. praetextata, from $4.17 \%$ to $18.64 \%$ in RCP 4.5 scenarios and from $4.57 \%$ to $21.51 \%$ in RCP 8.5 scenarios (Table 3 ). The newly suitable areas are expected to mainly occur at high elevation, in the central part of the Alps (Fig. 1a, c, 2a, 2c).

\subsection{Range change}

Range change (RC) values were mainly slightly negative, meaning that species are expected to experience a weak decrease in the overall range under both future climate change scenarios (Table 3). In particular, $P$. ponojensis was the only one species with positive values of RC, while Peltigera didactyla, P. elisabethae, $P$. neckeri, and $P$. venosa had more negative $\mathrm{RC}$ values in both scenarios (Table 3). In line with the low RG values, RC (RCP 4.5 scenario Kendal Tau correlation $=-0.83 ; \mathrm{p}<0.001 ; \mathrm{RCP} 8.5$ scenario Kendal Tau correlation $=-0.9 ; \mathrm{p}<0.001$ ) is negatively correlated with RL values.

\subsection{Range turnover}

Peltigera didactyla, P. elisabethae, P. neckeri, P. polydactylon, and $P$. venosa showed the highest values of range turnover (RT) in both RCP 4.5 and RCP 8.5 scenarios (Table 3 ). The Kendall tau correlation coefficient showed that the percentage of RT (4.5 scenario Kendal Tau correlation $=0.95 ; \mathrm{p}<0.001 ; 8.5$ scenario Kendal Tau correlation $=0.9 ; \mathrm{p}<0.001)$ is positively correlated with the percentage of RL.

\subsection{Relationship between range variations and species morpho- functional traits}

The first two factors of the PCA represented respectively 76.79\% and $23.17 \%$ of the total variance (Fig. 3 ). The two axes were correlated to all descriptors of range variation for both scenarios, and with selected functional traits. Particularly, the first axis was highly and significantly positively correlated with $\mathrm{RT}(\mathrm{r}=0.998 ; \mathrm{p}<0.0001)$ and $\mathrm{RL}(\mathrm{r}=0.986 ; \mathrm{p}<0.0001)$, and significantly negatively correlated with $\mathrm{RC}(\mathrm{r}=-0.931$ for 8.5 scenario, $\mathrm{r}=-0.865$ for 4.5 scenario; $\mathrm{p}<0.00001$ in both cases). Species with tomentum were associated with negative values of first axis $(r=-0.469 ; \mathrm{p}<0.05)$, and therefore with slightly positive or weakly negative RC values. In contrast, taxa with pruina on the upper cortex were positively associated with first axis $(r=0.362 ; p<0.05)$, and therefore with high RT and RL values. 
Table 2

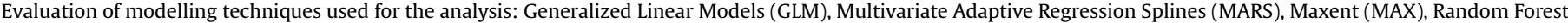

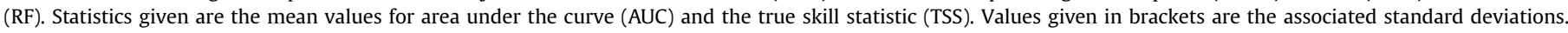
Accuracy classification for AUC: $1>$ excellent $>0.9>$ good $>0.8>$ fair $>0.7>$ poor $>0.6>$ fail; accuracy classification for TSS: $1>$ excellent $>0.8>$ good $>0.6>$ fair $>0.4>$ poor $>0.2>$ fail .

\begin{tabular}{|c|c|c|c|c|c|}
\hline Species & Evaluation & GLM & MARS & MAX & $\mathrm{RF}$ \\
\hline \multirow[t]{2}{*}{ P. aphthosa } & AUC & $0.896(0.013)$ & $0.872(0.045)$ & $0.913(0.003)$ & $0.970(0.003)$ \\
\hline & TSS & $0.701(0.024)$ & $0.699(0.104)$ & $0.693(0.015)$ & $0.840(0.009)$ \\
\hline \multirow[t]{2}{*}{ P. canina } & AUC & $0.893(0.011)$ & $0.852(0.048)$ & $0.912(0.005)$ & $0.962(0.004)$ \\
\hline & TSS & $0.681(0.029)$ & $0.664(0.044)$ & $0.674(0.01)$ & $0.805(0.013)$ \\
\hline \multirow[t]{2}{*}{ P. didactyla } & AUC & $0.864(0.014)$ & $0.867(0.023)$ & $0.892(0.004)$ & $0.963(0.002)$ \\
\hline & TSS & $0.624(0.025)$ & $0.652(0.045)$ & $0.635(0.014)$ & $0.803(0.012)$ \\
\hline \multirow[t]{2}{*}{ P. elisabethae } & AUC & $0.889(0.011)$ & $0.900(0.035)$ & $0.921(0.012)$ & $0.948(0.011)$ \\
\hline & TSS & $0.692(0.012)$ & $0.694(0.052)$ & $0.708(0.042)$ & $0.766(0.038)$ \\
\hline \multirow[t]{2}{*}{ P. kristinssonii } & AUC & $0.954(0.025)$ & $0.934(0.078)$ & $0.956(0.023)$ & $0.943(0.034)$ \\
\hline & TSS & $0.892(0.07)$ & $0.855(0.156)$ & $0.872(0.044)$ & $0.879(0.043)$ \\
\hline \multirow[t]{2}{*}{ P. lepidophora } & AUC & $0.907(0.01)$ & $0.872(0.04)$ & $0.907(0.011)$ & $0.950(0.01)$ \\
\hline & TSS & $0.728(0.021)$ & $0.692(0.078)$ & $0.700(0.03)$ & $0.798(0.019)$ \\
\hline \multirow[t]{2}{*}{ P. leucophlebia } & AUC & $0.916(0.006)$ & $0.897(0.03)$ & $0.938(0.004)$ & $0.973(0.004)$ \\
\hline & TSS & $0.752(0.02)$ & $0.740(0.059)$ & $0.765(0.01)$ & $0.852(0.014)$ \\
\hline \multirow[t]{2}{*}{ P. malacea } & AUC & $0.909(0.008)$ & $0.883(0.055)$ & $0.927(0.006)$ & $0.973(0.004)$ \\
\hline & TSS & $0.729(0.024)$ & $0.701(0.056)$ & $0.734(0.017)$ & $0.848(0.015)$ \\
\hline \multirow[t]{2}{*}{ P. neckeri } & AUC & $0.874(0.011)$ & $0.860(0.05)$ & $0.894(0.009)$ & $0.946(0.014)$ \\
\hline & TSS & $0.612(0.025)$ & $0.643(0.081)$ & $0.629(0.023)$ & $0.749(0.04)$ \\
\hline \multirow[t]{2}{*}{ P. polydactylon } & AUC & $0.869(0.011)$ & $0.885(0.026)$ & $0.907(0.004)$ & $0.956(0.006)$ \\
\hline & TSS & $0.642(0.017)$ & $0.676(0.049)$ & $0.684(0.013)$ & $0.791(0.015)$ \\
\hline \multirow[t]{2}{*}{ P. ponojensis } & AUC & $0.848(0.019)$ & $0.853(0.031)$ & $0.856(0.025)$ & $0.907(0.026)$ \\
\hline & TSS & $0.619(0.04)$ & $0.628(0.08)$ & $0.621(0.07)$ & $0.701(0.047)$ \\
\hline \multirow[t]{2}{*}{ P. praetextata } & AUC & $0.919(0.011)$ & $0.896(0.028)$ & $0.935(0.002)$ & $0.977(0.002)$ \\
\hline & TSS & $0.747(0.023)$ & $0.724(0.046)$ & $0.731(0.006)$ & $0.85(0.007)$ \\
\hline \multirow[t]{2}{*}{ P. rufescens } & AUC & $0.881(0.011)$ & $0.862(0.028)$ & $0.902(0.005)$ & $0.962(0.003)$ \\
\hline & TSS & $0.649(0.023)$ & $0.621(0.059)$ & $0.64(0.017)$ & $0.803(0.009)$ \\
\hline \multirow[t]{2}{*}{ P. scabrosa } & AUC & $0.893(0.008)$ & $0.878(0.037)$ & $0.913(0.01)$ & $0.966(0.006)$ \\
\hline & TSS & $0.737(0.016)$ & $0.719(0.071)$ & $0.711(0.023)$ & $0.839(0.018)$ \\
\hline \multirow[t]{2}{*}{ P. venosa } & AUC & $0.914(0.009)$ & $0.936(0.043)$ & $0.924(0.005)$ & $0.962(0.006)$ \\
\hline & TSS & $0.722(0.018)$ & $0.797(0.084)$ & $0.726(0.013)$ & $0.807(0.017)$ \\
\hline
\end{tabular}

The second axis was positively correlated with RG in both scenarios $(\mathrm{r}=0.808, \mathrm{p}<0.001)$. Species with vegetative reproduction were associated with positive values of second axis $(r=0.522$; $\mathrm{p}<0.0001)$, and species with thin thalli $(\mathrm{r}=-0.553 ; \mathrm{p}<0.0001)$ were associated with negative values of second axis, and therefore with low RG.

\section{Discussion}

Our results indicate moderate range dynamics for the terricolous species of the genus Peltigera in the Alps under a climate change scenario. This would imply a relative stability and resistance of these terricolous lichen communities to climate change that may reflect the local persistence (i.e. resistance to extirpation) of the species under sub-optimal conditions (Alexander et al., 2017). However, range loss is expected to occur mainly at low elevation and in peripheral areas of the Alps and to be only partially buffered by range gain at higher elevation, in the inner core of the Alps. This pattern is corroborated by the correlation between RL and both RC and RT, indicating that variations in distribution are expected to be mainly related to species range reduction rather than to the colonization of newly suitable areas. Results also support the view that species behavior, in terms of range dynamics, could be associated with functional traits mainly related to water-use strategies and to a trade-off between dispersal and establishment ability. These groups of traits are respectively directly and indirectly correlated to climatic factors. In climate change scenarios, these features may circumscribe the ability of the species to acclimatize and migrate under altered environmental conditions (Ellis, 2019).

Species with very low range dynamic values are mainly generalists that are currently distributed along a wide elevational gradient, as in the case of $P$. praetextata, $P$. canina, and $P$. rufescens. In contrast, species with more sensitive range dynamics are mainly those with their optimum in the montane belt, as in the case of $P$. elisabethae, $P$. neckeri, and P. polydactylon. However, while the former species are expected to buffer range losses in the lower part of the elevational gradient and in the peripheral areas of the Alps with range gain at higher elevations in the inner part of the mountain chain, the two latter species are expected to be poorly compensated in their range losses. Species mainly related to subalpine-alpine belts (e.g. P. malacea, P. aphthosa, P. leucophlebia) have moderate range dynamics and are expected to track their climatic suitability shifting to higher elevations, in the inner part of the Alps. However, among them, two species seem to be prone to high range loss: $P$. didactyla and $P$. venosa. The former is an ephemeral lichen of disturbed mineral soil (Nimis, 2016). It, thus, behaves as a stress-tolerant species that could be overwhelmed by more competitive species that are expanding their range upwards. The latter is mainly restricted to peculiar microhabitat conditions in cold humid sites (Nimis, 2016). It usually forms patchy populations on vertical, humus-rich soil in north exposed niches where it often occurs together with some already rare arctic-alpine lichens such as Nephroma expallidum, and Lobaria linita (Nascimbene and Caniglia, 2003). Our results are in line with general expectation on plants and animals that there will be a decrease of cryophilic species and an increase of thermophilic species at high altitude (Gottfried et al., 2012; Lamprecht et al., 2018; Rumpf et al., 2018). These processes may be the starting point of a structural modification of high elevation lichen communities.

We found that water use strategies, as well as trade-offs between dispersal and establishment ability were related to range dynamics under both future scenarios, probably because they enable terricolous lichens to resist to extirpation and to buffer range loss with potential range gain. This finding provides a mechanistic backbone to the expected patterns of range dynamics of terricolous lichens in the Alps. The high RL detected in species 


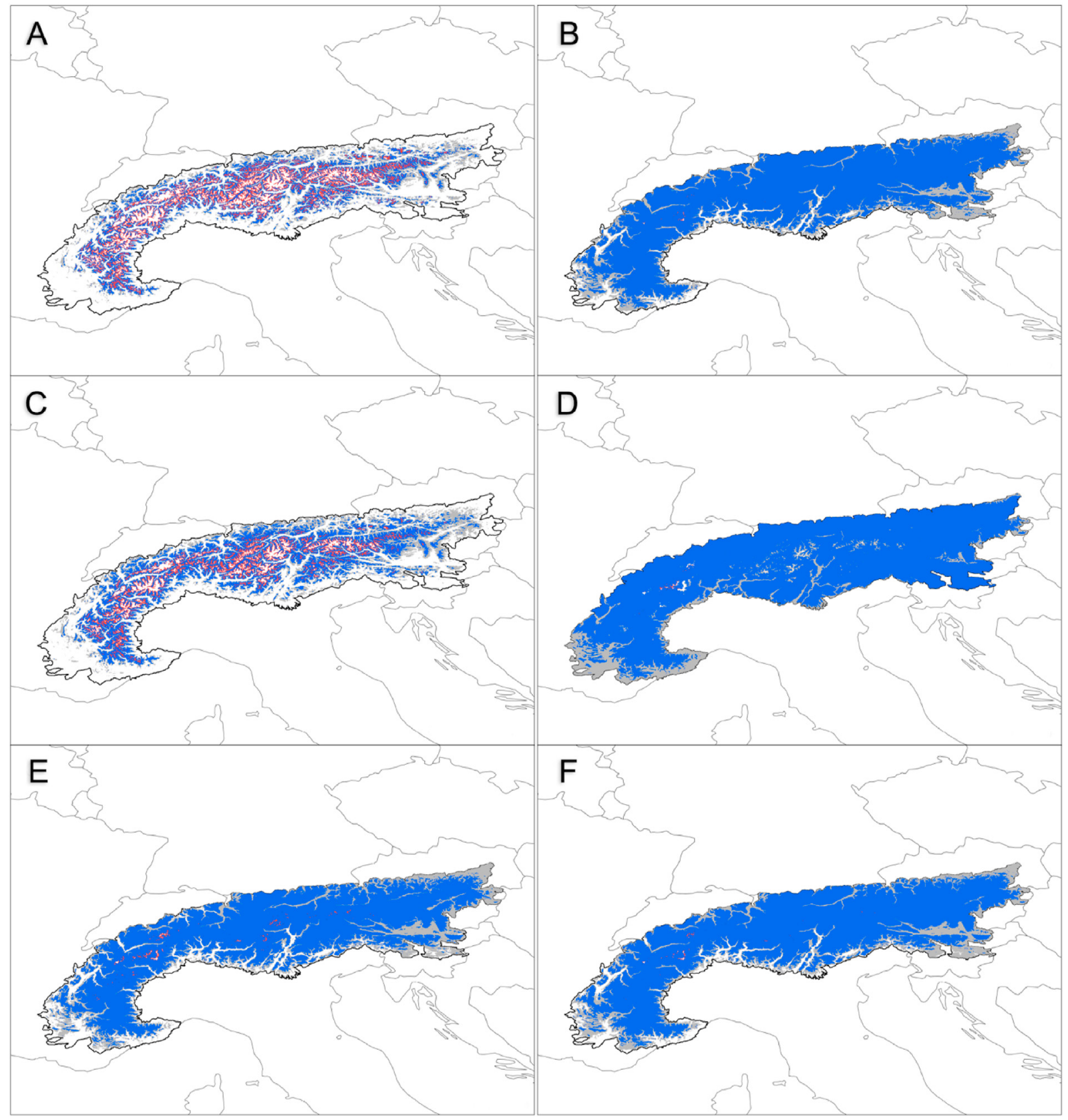

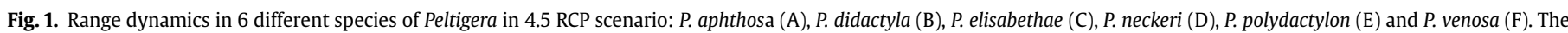

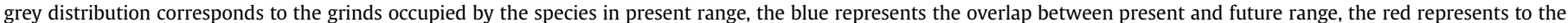
grinds that will be occupied by the species in future 4.5 RCP scenario.

producing pruina may be related to the fact that this character may be situation specific, favouring tolerance to provisional oxidative stress induced by light but not favouring species under future climate change. In contrast, the low RL detected in species having a tomentum on the upper cortex may be related to the capacity of tomentum to permanently protect species from dehydration making them more tolerant to the future climate. Moreover, species reproducing vegetatively and with thicker thalli show high RG gain values. On the one hand, thallus thickness may enhance the tolerance of the species to sub-optimal (i.e. warming and drying) conditions. In fact, a thicker thallus makes it possible to retain more water per unit of area, and to better cope with daily and seasonal variations in water availability (Gauslaa, 2014; Hurtado et al., 2020).
On the other hand, species that are mainly dispersed by asexual diaspores seem to meet a win-win trade-off in filling their climatic niche, implying that they could simultaneously track their suitable climates through effective local establishment. Despite the fact that asexual propagules are less suitable than sexual ascospores for long-range dispersal (Singh et al., 2015) they are more effective in local recruitment (Scheidegger and Werth, 2009; Nascimbene et al., 2017), enhancing the likelihood of establishment and persistence of new populations. In mountain regions, topographic complexity may result in spatial closeness between optimal and marginal environmental conditions (Soulé, 1973), so that effectiveness in local establishment may be more important than long dispersal capability in filling the potential climatic space. From perspective, 


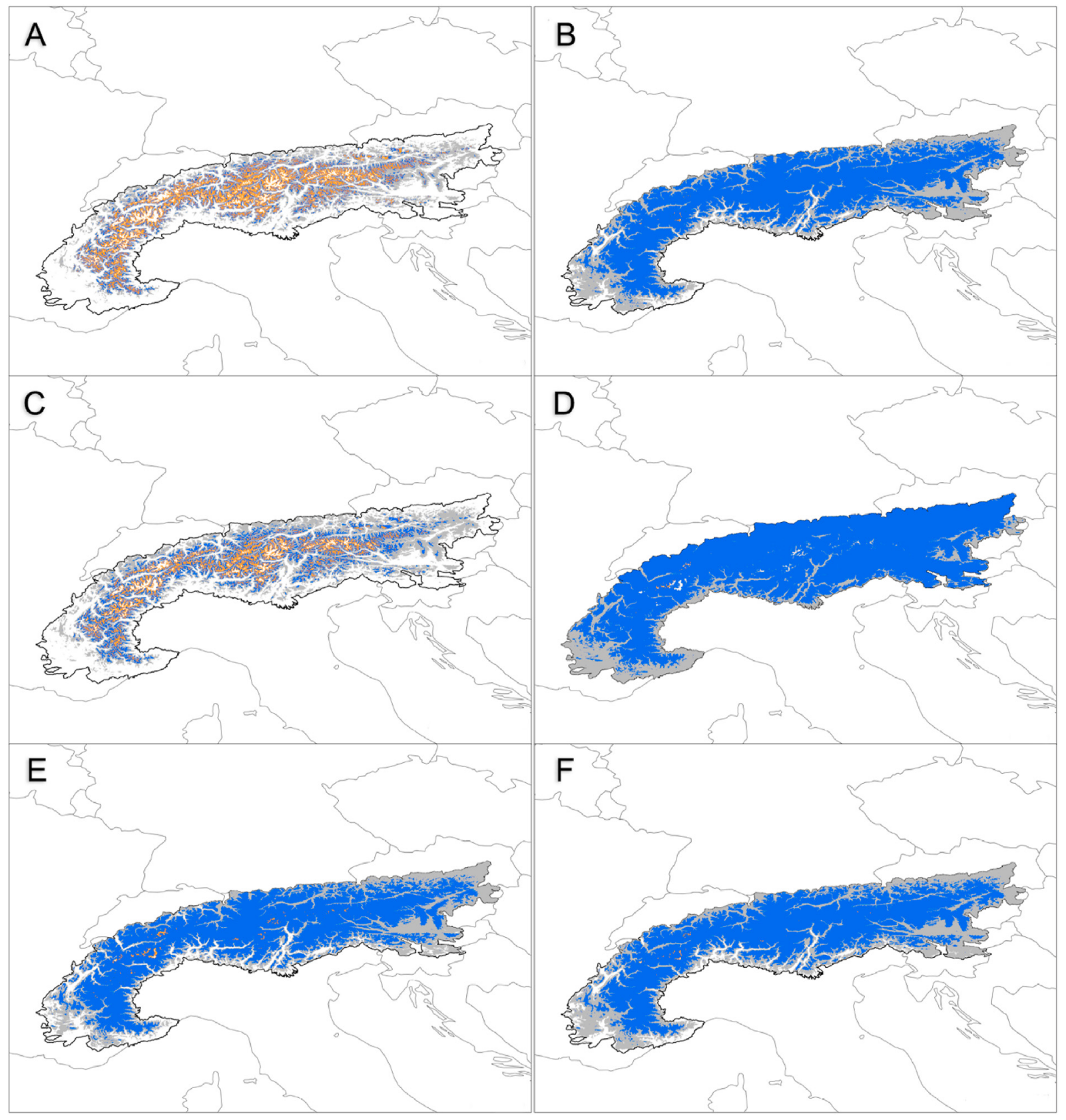

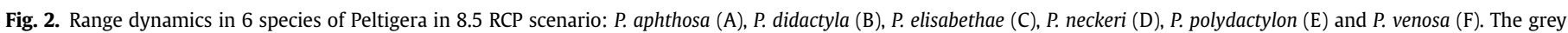

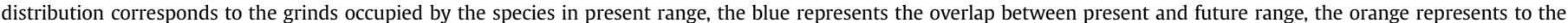
grinds that will be occupied by the species in future 8.5 RCP scenario.

species dispersing by asexual propagules may use a larger portion of their climatic space than species dispersing by ascospores, despite the fact that they are poorer dispersers. Moreover, the high establishment and persistence capacity may allow abundant and viable populations to cope with climate change, both enhancing their local resistance and ensuring moderate spatial shifts that avoid the risk of a mismatch between the mycobiont and the photobiont which would hamper the establishment of the lichen symbiosis. In contrast, sexual reproduction may enhance the capability of lichens to reach distant locations, but may weaken the likelihood of population establishment and persistence due to an inability to persist below a threshold density (Keitt et al., 2001).
Even ascospore producing species may fail to disperse over long distances (Morando et al., 2019) and this would represent a further disadvantage for these lichens. The moderate range dynamics that are forecasted by our models may reflect the capability of many species to resist to extirpation in the long term thanks to both effective water storage management and dispersal/establishment strategies. All these findings suggest that the lichen functional traits may strongly modulate the response to climate change, probably because species with similar functional traits are prone to similar selective pressures. These findings suggest that it may be possible to summarize species information into general groups showing recurring patterns of responses to climate change. 
Table 3

Percentage of the impacts of climate change on the distribution of 15 species of the genus Peltigera for the years 2061-2080 under 4.5 and 8.5 future scenarios. RC Percentage of Range change $(100 \times($ meanRG - meanRL)/meanPR), RG Percentage of Range gain ((meanRG/meanPR)x100); RL Percentage of Range loss ((meanRL/ meanPR)x100); RT Percentage of Range turnover $(100 \times($ meanRL + meanRG $) /$ (meanPR + meanRG)). Range dynamics were calculated using 5 General Circulation Models (CESM1-CAM5, CESM1-BGC, MIROC5, CMCC-CM and MP-ESM-MR) and two representative concentration pathways (RCP 4.5 and 8.5).

\begin{tabular}{|c|c|c|c|c|c|c|c|c|}
\hline \multirow[b]{2}{*}{ Species } & \multicolumn{4}{|c|}{4.5 future scenario } & \multicolumn{4}{|c|}{8.5 future scenario } \\
\hline & \%RG & $\% R L$ & $\%$ RC & \%RT & $\%$ RG & $\% R L$ & $\% \mathrm{RC}$ & \%RT \\
\hline P. aphthosa & 7.45 & 13.47 & -6.02 & 19.47 & 10.07 & 20.21 & -10.13 & 27.51 \\
\hline P. canina & 0.03 & 1.72 & -1.68 & 1.75 & 0.04 & 2.38 & -2.34 & 2.41 \\
\hline P. didactyla & 0.03 & 36.23 & -36.20 & 36.25 & 0.04 & 46.15 & -46.11 & 46.17 \\
\hline P. elisabethae & 18.64 & 41.02 & -22.38 & 50.29 & 21.51 & 61.96 & -40.46 & 68.70 \\
\hline P. kristinssonii & 5.33 & 8.31 & -2.98 & 12.95 & 4.78 & 12.41 & -7.63 & 16.40 \\
\hline P. lepidophora & 4.19 & 11.93 & -7.74 & 15.47 & 4.01 & 16.24 & -12.22 & 19.47 \\
\hline P. leucophlebia & 2.49 & 14.50 & -12.00 & 16.58 & 2.61 & 23.39 & -20.78 & 25.34 \\
\hline P. malacea & 0.06 & 11.63 & -11.57 & 11.68 & 0.06 & 19.03 & -18.97 & 19.08 \\
\hline P. neckeri & 0.59 & 25.93 & -25.34 & 26.37 & 0.58 & 34.51 & -33.93 & 34.88 \\
\hline P. polydactylon & 4.69 & 16.38 & -11.70 & 20.13 & 5.47 & 25.19 & -19.71 & 29.07 \\
\hline P. ponojensis & 2.61 & 1.02 & 1.59 & 3.54 & 2.61 & 2.21 & 0.40 & 4.70 \\
\hline P. praetextata & 4.17 & 6.49 & -2.32 & 10.23 & 4.57 & 8.64 & -4.07 & 12.64 \\
\hline P. rufescens & 3.67 & 6.66 & -3.00 & 9.97 & 4.20 & 11.58 & -7.38 & 15.14 \\
\hline P. scabrosa & 0.06 & 0.09 & -0.03 & 0.14 & 0.06 & 0.14 & -0.08 & 0.19 \\
\hline P. venosa & 1.64 & 30.69 & -29.06 & 31.81 & 2.11 & 42.25 & -40.13 & 43.44 \\
\hline
\end{tabular}

\section{Conclusions}

The application of predictive modelling to forecast the consequences of climate change on terricolous lichens of the Alps proved to be a useful initial approach to create anticipatory information in support of conservation activities devoted to this usually neglected organism group, which nevertheless greatly contributed to biodiversity and ecosystem functioning (Zedda and Rambold, 2015). In particular, coupling species distribution modelling with trait-based analysis provided a promising suggestion to better understand the underlying mechanisms that determine the response of these organisms to climate change.

However, we are aware that our results may fail to exhaustively unravel complex dynamics. We need more significant efforts to develop models that take formally into account various factors. Among others, some gaps to fill are:

- To explore the effect of the microclimate on the suitability of the species, to identify any microrefugia where the species have a higher probability of survival (Lenoir et al., 2017).

- To investigate the effects of climate change on biotic communities as a whole, to inform the species response when biotic interactions within lichen communities, and between terricolous lichens, mosses, and vascular plants, are taken into account (Giordani et al., 2019).

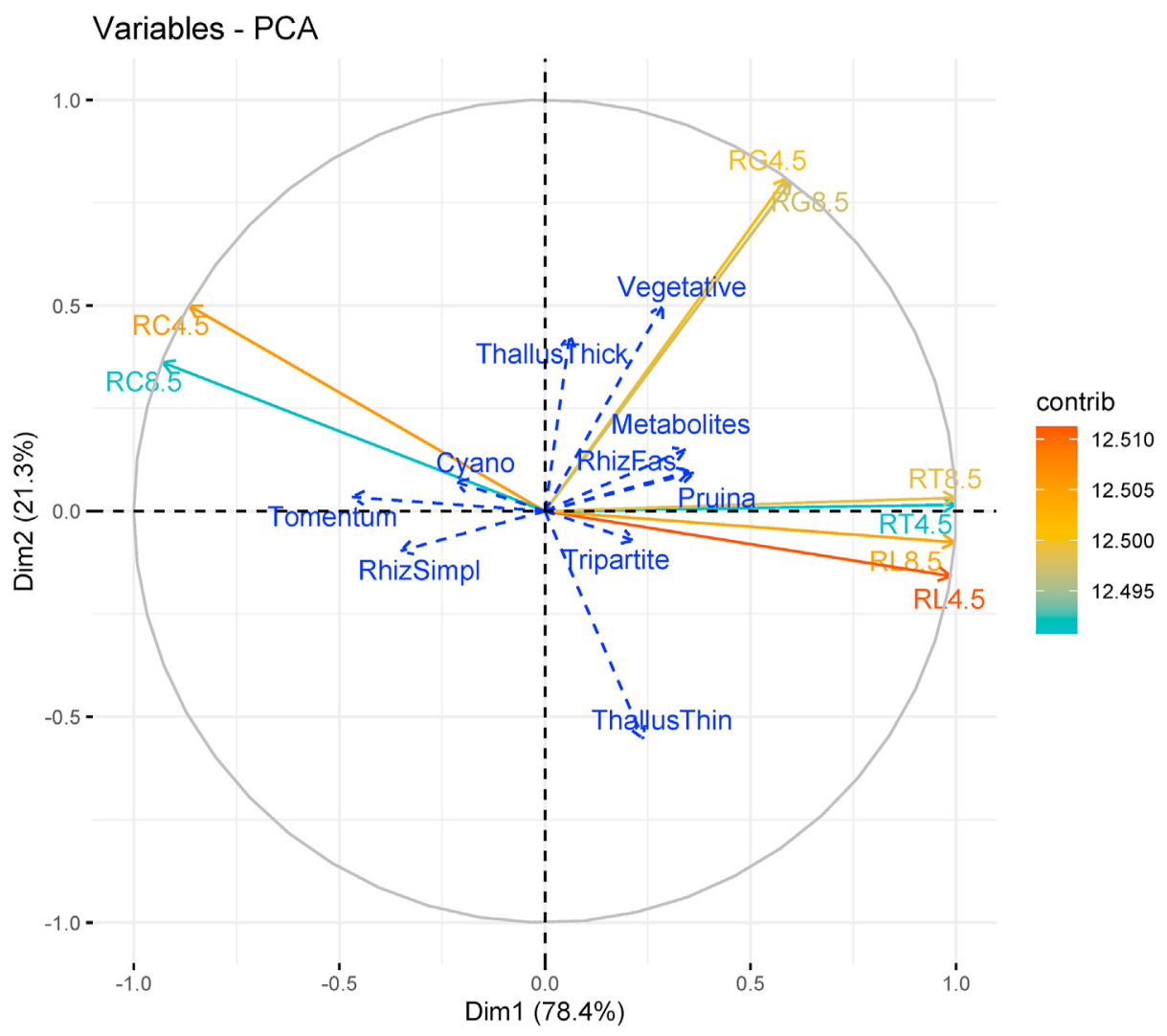

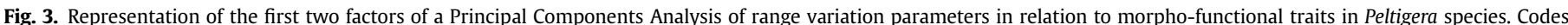

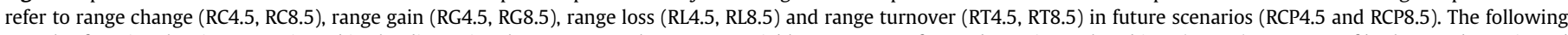

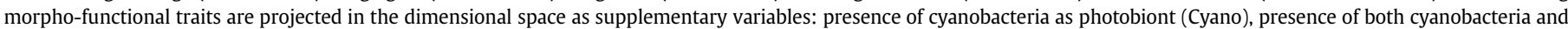

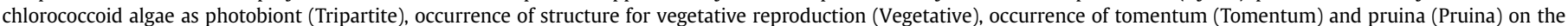

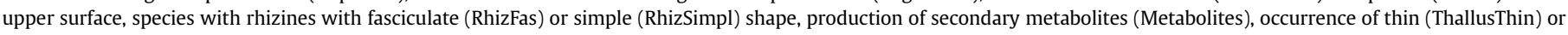
thick (ThallusThick) thallus. Contrib represents the percentage contribution of each variable to a given principal component. 
- To analyze the intraspecific response of functional traits to environmental drivers to determine the adaptation capacity of species to climate change (Hurtado et al., 2020).

\section{Acknowledgments}

Gabriele Casazza gratefully acknowledges financial support from the European Union's Horizon 2020 Research and Innovation Programme under grant agreement n. 793226.

\section{References}

Alexander, J.M., Chalmandrier, L., Lenoir, J., Burgess, T.I., Essl, F., Haider, S., Kueffer, C., McDougall, K., Milbau, A., Nuñez, M.A., Pauchard, A., Rabitsch, W., Rew, L.J., Sanders, N.J., Pellissier, L., 2017. Lags in the response of mountain plant communities to climate change. Global Change Biol. 24, 563-579. https://doi.org/ $10.1111 /$ gcb.13976.

Allouche, O., Tsoar, A., Kadmon, R., 2006. Assessing the accuracy of species distribution models: prevalence, kappa and the true skill statistic (TSS). J. Appl. Ecol. 43, 1223-1232. https://doi.org/10.1111/j.1365-2664.2006.01214.x.

Barbet-Massin, M., Jiguet, F., Albert, C.H., Thuiller, W., 2012. Selecting pseudoabsences for species distribution models: how, where and how many? Methods Ecol. Evol. 3, 327-338. https://doi.org/10.1111/j.2041210X.2011.00172.x.

Bässler, C., Cadotte, M.W., Beudert, B., Heibl, C., Blaschke, M., Bradtka, J.H., Langbehn, T., Werth, S., Mï i $1 / 2$ ller, J., 2016. Contrasting patterns of lichen functional diversity and species richness across an elevation gradient. Ecography (Cop.). 39, 689-698. https://doi.org/10.1111/ecog.01789.

Beaumont, L.J., Hughes, L., Pitman, A.J., 2008. Why is the choice of future climate scenarios for species distribution modelling important? Ecol. Lett. 11, 1135-1146. https://doi.org/10.1111/j.1461-0248.2008.01231.x.

Bellard, C., Bertelsmeier, C., Leadley, P.W., Thuiller, W., Courchamp, F., 2012. Impacts of climate change on the future of biodiversity $15,365-377$. https://doi.org/ 10.1111/j.1461-0248.2011.01736.x.

Brambilla, M., Ficetola, G.F., 2012. Species distribution models as a tool to estimate reproductive parameters: a case study with a passerine bird species. J. Anim. Ecol. 81, 781-787. https://doi.org/10.1111/j.1365-2656.2012.01970.x.

Breiman, L., 2001. Statistical modeling: the two cultures. Stat. Sci. 16, 199-231. https://doi.org/10.1214/ss/1009213726.

Cao, Y., DeWalt, R.E., Robinson, J.L., Tweddale, T., Hinz, L., Pessino, M., 2013. Using Maxent to model the historic distributions of stonefly species in Illinois streams: the effects of regularization and threshold selections. Ecol. Model. 259, 30-39. https://doi.org/10.1016/j.ecolmodel.2013.03.012.

Carniel, F.C., Gerdol, M., Montagner, A., Banchi, E., De Moro, G., Manfrin, C., Muggia, L., pallavicini, A., Tretiach, M., 2016. New features of desiccation tolerance in the lichen photobiont Trebouxia gelatinosa are revealed by a transcriptomic approach. Plant Mol. Biol. 91, 319-339. https://doi.org/10.1007/ s11103-016-0468-5.

Casazza, G., Giordani, P., Benesperi, R., Foggi, B., Viciani, D., Filigheddu, R., Farris, E., Bagella, S., Pisanu, S., Mariotti, M.G., 2014. Climate change hastens the urgency of conservation for range-restricted plant species in the central-northern Mediterranean region. Biol. Conserv. 179, 129-138.

Chen, I.C., Hill, J.K., Ohlemüller, R., Roy, D.B., Thomas, C.D., 2011. Rapid range shifts of species associated with high levels of climate warming. Science 333, 1024-1026. https://doi.org/10.1126/science.1206432.

Dainese, M., Aikio, S., Hulme, P.E., Bertolli, A., Prosser, F., Marini, L., 2017. Human disturbance and upward expansion of plants in a warming climate. Nat. Clim. Change 7, 577-580. https://doi.org/10.1038/NCLIMATE3337.

Dirnböck, T., Essl, F., Rabitsch, W., 2011. Disproportional risk for habitat loss of highaltitude endemic species under climate change. Global Change Biol. 17, 990-996. https://doi.org/10.1111/j.1365-2486.2010.02266.x.

Elbert, W., Weber, B., Burrows, S., Steinkamp, J., Büdel, B., Andreae, M.O., Pöschl, U., 2012. Contribution of cryptogamic covers to the global cycles of carbon and nitrogen. Nat. Geosci. 5, 459-462. https://doi.org/10.1038/ngeo1486.

Ellis, C.J., 2019. Climate change, bioclimatic models and the risk to lichen diversity. Diversity 11, 54. https://doi.org/10.3390/d11040054.

Escolar, C., Martínez, I., Bowker, M.A., Maestre, F.T., 2012. Warming reduces the growth and diversity of biological soil crusts in a semi-arid environment: implications for ecosystem structure and functioning. Philos. Trans. R. Soc. B Biol. Sci. 367, 3087-3099. https://doi.org/10.1098/rstb.2011.0344.

Fauquette, S., Suc, J.-P., Médail, F., Muller, S.D., J-M, G., Bertini, A., Martinetto, E., Popescu, S.-P., Zheng, Z., de Beaulieu, J.L., 2018. The Alps: a geological, climatic and human perspective on vegetation history and modern plant diversity. Mt. Clim. Biodivers. 413-428.

Freeman, E.A., Moisen, G.G., 2008. A comparison of the performance of threshold criteria for binary classification in terms of predicted prevalence and kappa. Ecol. Model. 217, 48-58. https://doi.org/10.1016/j.ecolmodel.2008.05.015.

Friedman, J.H., 1991. Multivariate adaptive regression splines. Ann. Stat. 19, 1-141.

Gauslaa, Y., 2014. Rain, dew, and humid air as drivers of morphology, function and spatial distribution in epiphytic lichens. Lichenologist 46, 1-16. https://doi.org/ 10.1017/S0024282913000753.
Gauslaa, Y., Solhaug, K.A., 2004. Photoinhibition in lichens depends on cortical characteristics and hydration. Lichenologist 36, 133-143. https://doi.org/ $10.1017 /$ S0024282904014045.

Giordani, P., Brunialti, G., Bacaro, G., Nascimbene, J., 2012. Functional traits of epiphytic lichens as potential indicators of environmental conditions in forest ecosystems. Ecol. Indicat. 18, 413-420. https://doi.org/10.1016/ j.ecolind.2011.12.006.

Giordani, P., Malaspina, P., Benesperi, R., Incerti, G., Nascimbene, J., 2019. Functional over-redundancy and vulnerability of lichen communities decouple across spatial scales and environmental severity. Sci. Total Environ. 666, 22-30. https://doi.org/10.1016/j.scitotenv.2019.02.187.

Giordani, P., Modenesi, P., Tretiach, M., 2003. Determinant factors for the formation of the calcium oxalate minerals, weddellite and whewellite, on the surface of foliose lichens. Lichenologist 35, 255-270. https://doi.org/10.1016/S00242829(03)00028-8.

Gobiet, A., Kotlarski, S., Beniston, M., Heinrich, G., Rajczak, J., Stoffel, M., 2014. 21st century climate change in the European Alps-A review. Sci. Total Environ. 493, 1138-1151. https://doi.org/10.1016/j.scitotenv.2013.07.050.

Gottfried, M., Pauli, H., Futschik, A., Akhalkatsi, M., Barančok, P., Benito Alonso, J.L., Coldea, G., Dick, J., Erschbamer, B., Fernández Calzado, M.R., Kazakis, G., Krajči, J., Larsson, P., Mallaun, M., Michelsen, O., Moiseev, D., Moiseev, P., Molau, U., Merzouki, A., Nagy, L., Nakhutsrishvili, G., Pedersen, B., Pelino, G., Puscas, M., Rossi, G., Stanisci, A., Theurillat, J.P., Tomaselli, M., Villar, L., Vittoz, P. Vogiatzakis, I., Grabherr, G., 2012. Continent-wide response of mountain vegetation to climate change. Nat. Clim. Change 2, 111-115. https://doi.org/ 10.1038/nclimate1329.

Goward, T., Goffinet, B., Vitikainen, O., 1995. Synopsis of the genus Peltigera (lichenized ascomycetes) in British Columbia, with a key to the north American species. Can. J. Bot. 73, 91-111. https://doi.org/10.1139/b95-012.

Green, T.G.A., Nash III, T.H., Lange, O.L., 2008. Physiological ecology of carbon dioxide exchange. Lichen Biology, pp. 152-181.

Grube, M., Cardinale, M., De Castro, J.V., Müller, H., Berg, G., 2009. Species-specific structural and functional diversity of bacterial communities in lichen symbioses. ISME J. 3, 1105-1115. https://doi.org/10.1038/ismej.2009.63.

Guerrina, M., Conti, E., Minuto, L., Casazza, G., 2016. Knowing the past to forecast the future: a case study on a relictual, endemic species of the SW Alps. Berardia subacaulis. Reg. Environ. Chang. 16, 1035-1045. https://doi.org/10.1007/s10113015-0816-z.

Guiot, J., Cramer, W., 2016. Climate change: the 2015 Paris Agreement thresholds and Mediterranean basin ecosystems. Science (80- 354, 465-468. https:// doi.org/10.1126/science.aah5015.

Hanley, J.A., McNeil, B.J., 1982. The meaning and use of the area under a receiver operating characteristic (ROC) curve. Radiology 143, 29-36. https://doi.org/ 10.1148/radiology.143.1.7063747.

Heinrich, G., Gobiet, A., Truhetz, H., Mendlik, T., 2013. Expected climate change and its uncertainty in the Alpine region: extended uncertainty assessment of the reclip: century and ENSEMBLES multi-model dataset. Wegener Center Scientific Report, p. 50.

Holland, M.M., Bitz, C.M., 2003. Polar amplification of climate change in coupled models. Clim. Dynam. 21, 221-232. https://doi.org/10.1007/s00382-003-0332

Hurtado, P., Prieto, M., Martínez-Vilalta, J., Giordani, P., Aragón, G., López-Angulo, J., Košuthová, A., Merinero, S., Díaz-Peña, E.M., Rosas, T., Benesperi, R., Bianchi, E., Grube, M., Mayrhofer, H., Nascimbene, J., Wedin, M., Westberg, M., Martínez, I., 2020. Disentangling functional trait variation and covariation in epiphytic lichens along a continent-wide latitudinal gradient. Proceedings. Biol. Sci. 287, 20192862. https://doi.org/10.1098/rspb.2019.2862.

Insarov, G., Schroeter, B., 2002. Lichen monitoring and climate change. Monitoring with Lichens - Monitoring Lichens. Springer, Dordrecht, pp. 183-201. https:// doi.org/10.1007/978-94-010-0423-7_13.

IPCC, 2014. In: Pachauri, R.K., Meyer, L.A. (Eds.), Climate Change 2014: Synthesis Report. Contribution of Working Groups I, II and III to the Fifth Assessment Report of the Intergovernmental Panel on Climate Change. IPCC, Geneva, Switz, p. 151.

Karger, D.N., Conrad, O., Böhner, J., Kawohl, T., Kreft, H., Soria-Auza, R.W., Zimmermann, N.E., Linder, H.P., Kessler, M., 2017. Climatologies at high resolution for the earth's land surface areas. Sci. Data 4, 1-20. https://doi.org/ 10.1038/sdata.2017.122.

Keitt, T.H., Lewis, M.A., Holt, R.D., 2001. Allee effects, invasion pinning, and species' borders. Am. Nat. 157, 203-216. https://doi.org/10.1086/318633.

Lamprecht, A., Semenchuk, P.R., Steinbauer, K., Winkler, M., Pauli, H., 2018. Climate change leads to accelerated transformation of high-elevation vegetation in the central Alps. New Phytol. 220, 447-459. https://doi.org/10.1111/nph.15290.

Lange, O.L., Kilian, E., Ziegler, H., 1986. Water vapor uptake and photosynthesis of lichens: performance differences in species with green and blue-green algae as phycobionts. Oecologia 71, 104-110. https://doi.org/10.1007/BF00377327.

Lê, S., Josse, J., Husson, F., 2008. FactoMineR: an R package for multivariate analysis. J. Stat. Software 25, 1-18. https://doi.org/10.18637/jss.v025.i01.

Lenoir, J., Gégout, J.C., Marquet, P.A., De Ruffray, P., Brisse, H., 2008. A significant upward shift in plant species optimum elevation during the 20th century. Science (80- 320, 1768-1771. https://doi.org/10.1126/science.1156831.

Lenoir, J., Hattab, T., Pierre, G., 2017. Climatic microrefugia under anthropogenic climate change: implications for species redistribution. Ecography (Cop.). 40, 253-266. https://doi.org/10.1111/ecog.02788.

Liu, C., Berry, P.M., Dawson, T.P., Pearson, R.G., 2005. Selecting thresholds of 
occurrence in the prediction of species distributions. Ecography (Cop.). 28, 385-393. https://doi.org/10.1111/j.0906-7590.2005.03957.x.

Loarie, S.R., Carter, B.E., Hayhoe, K., McMahon, S., Moe, R., Knight, C.A., Ackerly, D.D., 2008. Climate change and the future of California's endemic flora. PLoS One 3. https://doi.org/10.1371/journal.pone.0002502.

Löbel, S., Rydin, H., 2010. Trade-offs and habitat constraints in the establishment of epiphytic bryophytes. Funct. Ecol. 24, 887-897. https://doi.org/10.1111/j.13652435.2010.01705.x.

Marazzi, S., 2005. Atlante orografico delle Alpi: SOIUSA: suddivisione orografica internazionale unificata del sistema alpino. In: Priuli, Verlucca (Eds.), Pavone Canadese (TO). Italy.

Martínez, I., 1999. Taxonomía del género Peltigera Willd. (Ascomycetes liquenizados) en la Península Ibérica y estudio de sus hongos liquenícolas. Ruizia. Monogr. del Real Jardín Botánico 15, 1-200.

Matos, P., Pinho, P., Aragón, G., Martínez, I., Nunes, A., Soares, A.M.V.M., Branquinho, C., 2015. Lichen traits responding to aridity. J. Ecol. 103, 451-458. https://doi.org/10.1111/1365-2745.12364.

McCullagh, P., Nelder, J.A., 1989. Generalized Linear Models, second ed. Chapman \& Hall., London.

Merinero, S., Hilmo, O., Gauslaa, Y., 2014. Size is a main driver for hydration traits in cyano- and cephalolichens of boreal rainforest canopies. Fungal Ecol 7, 59-66. https://doi.org/10.1016/j.funeco.2013.12.001.

Modenesi, P., Piana, M., Giordani, P., Tafanelli, A., Bartoli, A., 2000. Calcium oxalate and medullary architecture in Xanthomaculina convoluta. Lichenologist 32, 505-512. https://doi.org/10.1006/lich.2000.0276.

Morando, M., Matteucci, E., Nascimbene, J., Borghi, A., Piervittori, R., FaveroLongo, S.E., 2019. Effectiveness of aerobiological dispersal and microenvironmental requirements together influence spatial colonization patterns of lichen species on the stone cultural heritage. Sci. Total Environ. 685, 1066-1074. https://doi.org/10.1016/j.scitotenv.2019.06.238.

Nagy, L., Grabherr, G., Körner, C., Thompson, D.B.A., 2003. Alpine Biodiversity in Europe. Springer Berlin Heidelberg.

Nascimbene, J., Caniglia, G., 2003. Materiale per una check-list dei licheni del Parco Naturale delle Dolomiti d'Ampezzo (Belluno-NE Italia). Lav. Soc. Ven. Sci. Nat $28,65-69$.

Nascimbene, J., Casazza, G., Benesperi, R., Catalano, I., Cataldo, D., Grillo, M., Isocrono, D., Matteucci, E., Ongaro, S., Potenza, G., Puntillo, D., Ravera, S., Zedda, L., Giordani, P., 2016. Climate change fosters the decline of epiphytic Lobaria species in Italy. Biol. Conserv. 201, 377-384. https://doi.org/10.1016/ j.biocon.2016.08.003.

Nascimbene, J., Mayrhofer, H., Dainese, M., Bilovitz, P.O., 2017. Assembly patterns of soil-dwelling lichens after glacier retreat in the European Alps. J. Biogeogr. 44, 1393-1404. https://doi.org/10.1111/jbi.12970.

Nascimbene, J., Spitale, D., 2017. Patterns of beta-diversity along elevational gradients inform epiphyte conservation in alpine forests under a climate change scenario. Biol. Conserv. 216, 26-32. https://doi.org/10.1016/ j.biocon.2017.09.021.

Nash, T.H., 2008. Lichen Biology, Second. Cambridge University Press.

Nimis, P.L., 2016. The Lichens of Italy. A Second Annotated Catalogue. EUT Edizioni Università di Trieste.

Nimis, P.L., Hafellner, J., Roux, C., Clerc, P., Mayrhofer, H., Martellos, S., Bilovitz, P.O., 2018. The lichens of the Alps - an annotated checklist. MycoKeys 31, 1-634. https://doi.org/10.3897/mycokeys.31.23658.

Nimis, P.L., Martellos, S., 2017. ITALIC - the Information System on Italian Lichens. University of Trieste, Dept. of Biology. Version 5.0. http://dryades.units.it/italic [WWW Document].

Oliver, M.J., Tuba, Z., Mishler, B.D., 2000. The evolution of vegetative desiccation tolerance in land plants. Plant Ecol. 151, 85-100. https://doi.org/10.1023/A: 1026550808557.

Parmesan, C., 2006. Ecological and evolutionary responses to recent climate change. Annu. Rev. Ecol. Evol. Syst. 37, 637-669. https://doi.org/10.1146/ annurevecolsys.37.091305.110100.

Pepin, N., Bradley, R.S., Diaz, H.F., Baraer, M., Caceres, E.B., Forsythe, N., Fowler, H., Greenwood, G., Hashmi, M.Z., Liu, X.D., Miller, J.R., Ning, L., Ohmura, A., Palazzi, E., Rangwala, I., Schöner, W., Severskiy, I., Shahgedanova, M., Wang, M.B., Williamson, S.N. Yang, D.O, Mountain Research Initiative, E.D.W.W.G., Pepin, N., Bradley, R.S., Diaz, H.F., Baraer, M., Caceres, E.B.,
Forsythe, N., Fowler, H., Greenwood, G., Hashmi, M.Z., Liu, X.D., Miller, J.R., Ning, L., Ohmura, A., Palazzi, E., Rangwala, I., Schöner, W., Severskiy, I., Shahgedanova, M., Wang, M.B., Williamson, S.N., Yang, D.Q., 2015. Elevationdependent warming in mountain regions of the world. Nat. Clim. Change 5 (5), 424-430. https://doi.org/10.1038/nclimate2563.

Phillips, S.B., Aneja, V.P., Kang, D., Arya, S.P., 2006. Maximum entropy modeling of species geographic distributions. Ecol. Model. 190, 231-259.

Phinney, N.H., Solhaug, K.A., Gauslaa, Y., 2018. Rapid resurrection of chlorolichens in humid air: specific thallus mass drives rehydration and reactivation kinetics. Environ. Exp. Bot. 148, 184-191. https://doi.org/10.1016 j.envexpbot.2018.01.009.

Pietrasiak, N., Regus, J.U., Johansen, J.R., Lam, D., Sachs, J.L., Santiago, L.S., 2013. Biological soil crust community types differ in key ecological functions. Soil Biol. Biochem. 65, 168-171. https://doi.org/10.1016/j.soilbio.2013.05.011.

R Development Core Team, 2008. R: A Language and Environment for Statistical Computing. R Foundation for Statistical Computing, Vienna, Austria.

Rands, M.R.W., Adams, W.M., Bennun, L., Butchart, S.H.M., Clements, A., Coomes, D., Entwistle, A., Hodge, I., Kapos, V., Scharlemann, J.P.W., Sutherland, W.J., Vira, B., 2010. Biodiversity conservation: challenges beyond 2010. Sci 329, 1298-1303. https://doi.org/10.1126/science.1189138.

Ronnås, C., Werth, S., Ovaskainen, O., Várkonyi, G., Scheidegger, C., Snäll, T., 2017. Discovery of long-distance gamete dispersal in a lichen-forming ascomycete. New Phytol. 216, 216-226. https://doi.org/10.1111/nph.14714.

Rumpf, S.B., Hülber, K., Klonner, G., Moser, D., Schütz, M., Wessely, J., Willner, W., Zimmermann, N.E., Dullinger, S., 2018. Range dynamics of mountain plants decrease with elevation. Proc. Natl. Acad. Sci. U. S. A. 115, 1848-1853. https:/ doi.org/10.1073/pnas.1713936115.

Sanderson, B.M., Knutti, R., Caldwell, P., 2015. A representative democracy to reduce interdependency in a multimodel ensemble. J. Clim. 28 (13), 5171-5194.

Scheidegger, C., Werth, S., 2009. Conservation strategies for lichens: insights from population biology. Fungal Biol. Rev. 23, 55-66. https://doi.org/10.1016/ j.fbr.2009.10.003.

Schmitz, O.J., Post, E., Burns, C.E., Johnston, K.M., 2003. Ecosystem Responses to Global Climate Change: Moving Beyond Color Mapping. Bioscience 53, 1199-1205. https://doi.org/10.1641/0006-3568(2003)053[1199:ertgcc]2.0.co;2.

Singh, G., Dal Grande, F., Werth, S., Scheidegger, C., 2015. Long-term consequences of disturbances on reproductive strategies of the rare epiphytic lichen Lobaria pulmonaria: clonality a gift and a curse. FEMS Microbiol. Ecol. 91, 1-11. https:// doi.org/10.1093/femsec/fiu009.

Snelgar, W.P., Green, T.G.A., 1981. Ecologically-linked variation in morphology, acytelene reduction and water relations in Pseudocyphellaria dissimilis. New Phytol. 87, 403-411. https://doi.org/10.1111/j.1469-8137.1981.tb03211.x.

Soberón, J., 2010. Niche and area of distribution modeling: a population ecology perspective. Ecography 33, 159-167. https://doi.org/10.1111/j.16000587.2009.06074.x.

Thuiller, A.W., Georges, D., Engler, R., Georges, M.D., Thuiller, C.W., 2016. Package 'biomod2'. Ensemble platform for species distribution modeling, pp. 1-104.

Soulé, M., 1973. The epistasis cycle: a theory of marginal populations. Annu. Rev. Ecol. Systemat. 4, 165-187. https://doi.org/10.1146/ annurev.es.04.110173.001121.

Thuiller, W., Lavorel, S., Araújo, M.B., Sykes, M.T., Prentice, I.C., 2005. Climate change threats to plant diversity in Europe. Proc. Natl. Acad. Sci. U. S. A. 102, 8245-8250. https://doi.org/10.1073/pnas.0409902102.

Türk, R., Gärtner, G., 2001. Biological soil crusts of the subalpine, alpine, and nival areas in the Alps. Biological Soil Crusts: Structure, Function, and Management. Springer, Berlin, Heidelberg, pp. 67-73. https://doi.org/10.1007/978-3-64256475-8_5.

Vitikainen, O., 1994. Taxonomic revision of Peltigera (lichenized ascomycotina) in Europe. Acta Bot. Fennica 154, 1-96.

Werth, S., Cheenacharoen, S., Scheidegger, C., 2014. Propagule size is not a good predictor for regional population subdivision or fine-scale spatial structure in lichenized fungi. Fungal Biol 118, 126-138. https://doi.org/10.1016/ j.funbio.2013.10.009.

Zedda, L., Rambold, G., 2015. The diversity of lichenised fungi: ecosystem functions and ecosystem services. Recent Advances in Lichenology. Springer, New Delhi, pp. 121-145. 